\title{
EFFECT OF FOLIAR APPLICATION OF HUMIC ACID AND BENZYLADENINE ON GROWTH AND FLOWERING OF POT MARIGOLD (Calendula officinalis L.)
}

\author{
Ameena Mohammed Hasan \\ Dept. Of Horticulture, College of Agriculture, University of Duhok, Kurdistan Region - Iraq
}

(Received: June 26, 2018; Accepted for Publication: December 4, 2018)

\begin{abstract}
The experiment was conducted at the Horticultural Department, College of Agriculture, Duhok University, during growing season from October, 2017 to April, 2018. To study the effect of humic acid and benzyladenine on the growth and flowering development of pot marigold, the seedlings which growth of transplanted in to plastic bag which were spray with three concentrations of humic acid $(\mathrm{HA})(0,0.05,0.1$ and 0.15) $\mathrm{g}^{-1}$ and benzyladenine (BA) $\left(0,50,100\right.$ and 150) $\mathrm{mg} \mathrm{I}^{-1}$. The results show that treated plants with $\mathrm{HA}$ at $0.15 \mathrm{~g} \mathrm{I}^{-1}$ led to positive effect in no. of leaves/ plant, fresh weight of roots/plant, days required to inflorescence bud initiation, no. of days remain inflorescence on the plant, no. of ray flowers/ inflorescence, dry weight of inflorescence and vas life, also it was noticed that the no. of lateral branches, $(E-W)$ plant spread, fresh weight of vegetative growth/ plant, no. of days required to convert inflorescence bud to full inflorescence and inflorescence diameter was observed at $150 \mathrm{mg} \mathrm{I}^{-1}$ of BA.
\end{abstract}

KEYWORDS: Calendula officinalis, Humic Acid, Benzyladenine, Vegetative and Flowering Growth.

\section{INTRODUCTION}

$\mathbf{P}$ ot marigold (Calendula officinalis L.) is an annual herbaceous plant and a member of Asteraceae family. It's known as pot marigold, common marigold, garden marigold, English marigold, or Scottish marigold. It is cultured as rock gardens, borders, flower beds and balcony plants (Golestani et al. 2013). Rigane et al. (2013) illustrated that the pot marigold originated from Mediterranean countries, Eastern and Southern Europe and planted usually in North America, Eastern Europe, Germany and India. Pot marigold yellow and orange flowers rich by vitamin $\mathrm{A}$, flavonoids, carotenoids, essential oils and mucilage substances. As well as it grown as an ornamental plant it has many medicinal benefits blood refiner, blood sugar decreasing, antiinflammatory, skin anti-fungal and anti-viral characters (Mohammad and Kashani, 2012).

Plant fertilization is necessary for increasing yield and quality. The mineral fertilizer increase crop yield, while excessive its uses can be have reverse environmental influences, such applications result in the increase amount of heavy metals, especially $\mathrm{Cd}, \mathrm{Pb}$, and $\mathrm{As}$ in the soil (Atafar et al., 2010).Therefore, it is necessary to use other resources of nutrients for plants which cause highest proportion of yields with least environmental influences. Humic acid is a complex heterogeneous blend of organic material product from the decay of plant and animal residue (MacCarthy et al., 1990). Humic acid is one of organic fertilizers has been applied for research in different scope of agriculture, like soil chemistry, fertility, plant physiology in addition to environmental sciences because of the various effects on plant growth (Tan,1998). Gadimov et al. (2007) have reported that the potassium humate enhance in plants growth quality and tolerance of plant to drought, saline, cold, diseases and pests infection. Arancon et al. (2003) who explained that HA improve growth of marigolds (Tagetes patula L. 'Antigua Gold'), also enhanced yield and quality of flowers of gerbera (Nikbakht et al., 2015). Highest fresh weight of flowers was appeared by using of humic acid on (Calendula officinalis L.) flowers (Mohammadipour et al. 2012). Fan et al. (2014) reported that foliar treatment of humic acid on chrysanthemum increased the growth and development that enhance net photosynthetic rate due to the high content of chlorophyll. Humic acid at high concentrations increased flowering and yield of gladiolus (Baldotto and Baldotto, 2013). 
Plant growth regulators (PGRs) are an organic complex, either natural or synthetic which regulate or controls one or more particular physiological processes in the plant. The use of plant growth regulators is one of the factors in increasing the growth, yield and flower quality of plants (Nuvale et al., 2010). The most influences of cytokinins in plants are stimulation of cell division and enlargement, and the delaying of senescence (Mooney and Van Staden, 1986). Benzyladenine has recently used to improve the quality of different ornamental plants (Han, 2001). Eraki (1994) in his study on Hibiscus sabdarijfa L. plants stated that use of BA significantly increased plant height, number of branches in additional of fresh and dry weights of leaves. Mutui et al. (2004) stated that the adding of BA at 25 or $50 \mathrm{mg}$ $1^{-1}$ increased the number of days to full opening of primary florets and delayed the start of flower senescence of Alstroemeria cut flowers. Foliar application of BA on pot marigold increased growth of different organs, active constituent's productions and total carbohydrates content as compare to the untreated plants (Menesi et al. 1991). BA causes increase in general growth on croton compared with control treatment as reported by (Rawia and Bedou, 2006).

This study was designed to evaluate the effect of Humic acid and Benzyladenine on vegetative growth and flowering yield of pot marigold.

\section{MATERIALS AND METHODS}

The study was carried out in the Horticultural Department, College of Agriculture, University of Duhok, Kurdistan Region, Iraq, during growing season from October, 2017 to April, 2018. Local seeds of pot marigold were sowing in basin after four weeks of germination seedling were transplanted in to the nursery bags size $(12 \times 30)$ $\mathrm{cm}$ were filled with a mixture of media that consists of garden sand and sheep manure and petmose 1:1:1 (v/v) with 1 plant/ bag. Three concentrations of humic acid (HA) $(0.05,0.1$ and $0.15) \mathrm{g} \mathrm{l}^{-1}$ and benzyladenine (BA) (50, 100 and 150) $\mathrm{mg} \mathrm{l}^{-1}$ were used as well as to control. Plants sprayed by these materials three times within ten days intervals starting after two weeks of seedlings transplanting. All agricultural and horticultural practices were achieved for the plants under the study. All plants were harvested in the April, vegetative and flowering characters measured, after then dried in oven at $70^{\circ} \mathrm{C}$ for 72 hours, then dry plant parameters measured. Randomized Complete Block Design (RCBD) was used for perform this experiment and statistical analysis by using SAS program (SAS, 2007).

The study parameters included the following:

\section{1 -Vegetative growth properties: -}

Number of leaves/ plant, no. of main branches, no. of lateral branches, $(\mathrm{N}-\mathrm{S})$ plant spread $(\mathrm{cm})$, (E-W) plant spread $(\mathrm{cm})$, total chlorophyll in leaves (SPAD), fresh weight of vegetative growth/ plant $(\mathrm{g})$, fresh weight of roots/ plant (g), dry weight of vegetative growth/ plant (g), dry weight of roots/ plant $(\mathrm{g})$ and roots length $(\mathrm{cm})$.

\section{2- Flowering growth properties:-}

Days required to inflorescence bud initiation, no. of days required to convert inflorescence bud to full inflorescence (after 50\% from bud initiation), no. of days remain inflorescence on the plant, no. of inflorescences/ plant, length of inflorescence stalk $(\mathrm{cm})$, inflorescence diameter (cm), no. of ray flowers/ inflorescence, fresh weight of inflorescence (g), dry weight of inflorescence ( $\mathrm{g}$ ) and vas life (days).

\section{RESULTS}

\section{1- Vegetative growth properties}

The results in Table (1) Clearly showed the effect of humic acid and benzyladenine on some characters of pot marigold. It appeared that there are significant increases in number of leaves/ plant which reached to (150.55 leaves) when plants sprayed with $0.15 \mathrm{~g} \mathrm{l}^{-1}$ humic acid as compared to the other concentrations and untreated plant (control), the second concentration of humic acid $\left(0.1 \mathrm{~g} \mathrm{l}^{-1}\right)$ had a significant increase in the no. of main branches (9.17 branches) was noticed as compared to the other treatments. Whereas, spraying pot marigold plants with BA at $150 \mathrm{mg} \mathrm{l}^{-}$ ${ }^{1}$ gave the best no. of lateral branches (26.50 branches) as compared to the control which produce least lateral branches (19.50). The (N-S) and $(\mathrm{E}-\mathrm{W})$ plant spread wasn't reached to the significant level when plants sprayed with different concentrations of humic acid and benzyladenine but it significantly increased as compared to control treatment. 
Table (1): Effect of humic acid and benzyladenine on number of leaves/ plant, no. of main branches, no. of lateral branches, (N-S) plant spread and (E-W) plant spread of pot marigold.

\begin{tabular}{|c|c|c|c|c|c|}
\hline conc. & $\begin{array}{c}\text { Number of leaves/ } \\
\text { plant }\end{array}$ & $\begin{array}{c}\text { No. of main } \\
\text { branches }\end{array}$ & $\begin{array}{c}\text { No. of lateral } \\
\text { branches }\end{array}$ & $\begin{array}{l}\text { (N-S) plant } \\
\text { spread }(\mathrm{cm})\end{array}$ & $(E-W)$ plant spread $(\mathrm{cm})$ \\
\hline Control & $106.00 \mathrm{~d}$ & $5.39 c$ & $19.50 \mathrm{~b}$ & $31.50 \mathrm{~b}$ & $10.66 \mathrm{~b}$ \\
\hline HA $0.05 \mathrm{~g} \mathrm{l}^{-1}$ & $135.89 \mathrm{~b}$ & $6.17 \mathrm{bc}$ & $25.77 \mathrm{a}$ & $35.62 \mathrm{ab}$ & $24.22 \mathrm{a}$ \\
\hline HA $0.1 \mathrm{~g} \mathrm{l}^{-1}$ & $123.55 \mathrm{c}$ & $9.17 \mathrm{a}$ & $26.00 \mathrm{a}$ & $36.49 \mathrm{a}$ & $24.03 \mathrm{a}$ \\
\hline HA $0.15 \mathrm{~g} \mathrm{I}^{-1}$ & $150.55 \mathrm{a}$ & $7.05 \mathrm{~b}$ & $25.78 \mathrm{a}$ & $34.49 a b$ & $28.58 \mathrm{a}$ \\
\hline BA $150 \mathrm{mg} \mathrm{l}^{-1}$ & $107.61 \mathrm{~d}$ & $6.28 \mathrm{bc}$ & $21.39 \mathrm{~b}$ & $35.38 \mathrm{ab}$ & $24.62 \mathrm{a}$ \\
\hline BA $100 \mathrm{mg} \mathrm{l}^{-1}$ & $127.17 \mathrm{bc}$ & $6.67 \mathrm{bc}$ & $25.50 \mathrm{a}$ & $36.69 \mathrm{a}$ & $27.42 \mathrm{a}$ \\
\hline BA $150 \mathrm{mg} \mathrm{l}^{-1}$ & $124.11 \mathrm{c}$ & $7.50 \mathrm{~b}$ & $26.50 \mathrm{a}$ & $34.93 a b$ & $29.33 \mathrm{a}$ \\
\hline
\end{tabular}

* Mean with the same letter and each parameter are not significantly different at 0.05 level according to Duncan multiple range test.

Table (2) Explains that the total chlorophyll content in leaves of pot marigold was significantly influenced by various concentrations of humic acid and benzyladenine compared to control that gave lower content of it. Spraying plants with $150 \mathrm{mgl}^{-1} \mathrm{BA}$ caused significant increase in the amount of fresh weight of vegetative growth/ plant (48.43 g) as compared to untreated plants which reached to (31.93) g, while, a significant increase in the fresh weight of roots/ plant (19.17 g) was obtained since the plants sprayed with $0.15 \mathrm{~g} \mathrm{l}^{-1}$ humic acid compared to plants treated with 50 $\mathrm{mg}^{-1} \mathrm{BA}$ and control. Dry weight of vegetative growth/ plant was not significantly affected by the different concentrations of humic acid and benzyladenine but it was significantly increase as compared to the control, meanwhile humic acid at $0.1 \mathrm{~g} \mathrm{l}^{-1}$ recorded best values (4.41 g) and $(34.53 \mathrm{~cm})$ of dry weight of roots/ plant and roots length respectively, as compared to other treatments and control.

Table (2): Effect of humic acid and benzyladenine on total chlorophyll in leaves, fresh weight of vegetative growth/ plant, fresh weight of roots/ plant, dry weight of vegetative growth/ plant, dry weight of roots/ plant and roots length of pot marigold.

\begin{tabular}{|c|c|c|c|c|c|c|}
\hline conc. & $\begin{array}{c}\text { Total } \\
\text { chlorophyll in } \\
\text { leaves (SPAD) }\end{array}$ & $\begin{array}{c}\text { Fresh weight } \\
\text { of vegetative } \\
\text { growth/ plant } \\
\text { (g) }\end{array}$ & $\begin{array}{c}\text { Fresh } \\
\text { weight of } \\
\text { roots/ plant } \\
\text { (g) } \\
\end{array}$ & $\begin{array}{c}\text { Dry weight of } \\
\text { vegetative } \\
\text { growth/ plant } \\
\text { (g) }\end{array}$ & $\begin{array}{l}\text { Dry weight } \\
\text { of roots/ } \\
\text { plant }(g)\end{array}$ & Roots length (cm) \\
\hline Control & $33.58 \mathrm{~b}$ & $31.93 \mathrm{c}$ & $7.96 \mathrm{c}$ & $3.32 \mathrm{~b}$ & $2.80 \mathrm{~cd}$ & $22.58 d$ \\
\hline HA $0.05 \mathrm{~g} \mathrm{l}^{-1}$ & $39.68 \mathrm{a}$ & $38.02 \mathrm{bc}$ & $17.13 \mathrm{a}$ & $6.47 \mathrm{a}$ & $3.63 \mathrm{a}-\mathrm{c}$ & $31.25 \mathrm{ab}$ \\
\hline HA $0.1 \mathrm{~g} \mathrm{I}^{-1}$ & $41.08 \mathrm{a}$ & $40.60 \mathrm{~b}$ & $18.55 \mathrm{a}$ & $6.24 \mathrm{a}$ & $4.41 \mathrm{a}$ & $34.53 \mathrm{a}$ \\
\hline HA $0.15 \mathrm{~g} \mathrm{l}^{-1}$ & $41.87 \mathrm{a}$ & $42.81 \mathrm{ab}$ & $19.17 \mathrm{a}$ & $6.97 \mathrm{a}$ & $4.23 a$ & $32.67 \mathrm{a}$ \\
\hline BA $50 \mathrm{mg} \mathrm{l}^{-1}$ & $40.50 \mathrm{a}$ & $42.11 \mathrm{ab}$ & $8.46 \mathrm{c}$ & $6.10 \mathrm{a}$ & $2.29 d$ & $26.21 b-d$ \\
\hline BA $100 \mathrm{mg} \mathrm{l}^{-1}$ & $43.02 \mathrm{a}$ & $41.55 \mathrm{ab}$ & $15.85 \mathrm{ab}$ & $7.56 \mathrm{a}$ & $3.71 \mathrm{ab}$ & $29.80 \mathrm{a}-\mathrm{c}$ \\
\hline BA $150 \mathrm{mg} \mathrm{l}^{-1}$ & $39.87 \mathrm{a}$ & $48.43 \mathrm{a}$ & $11.31 \mathrm{bc}$ & $6.45 \mathrm{a}$ & $2.86 \mathrm{~b}-\mathrm{d}$ & $25.53 \mathrm{~cd}$ \\
\hline
\end{tabular}

* Mean with the same letter and each parameter are not significantly different at 0.05 level according to Duncan multiple range test. 


\section{2- Flowering growth properties}

The data present in Table (3) Shows that the spraying pot marigold plants with different concentrations of humic acid and benzyladenine led to reduce the no. of days required to inflorescence bud initiation, the best treatment (least days required to inflorescence bud initiation) (55.88 days) was noticed when plants sprayed with $0.15 \mathrm{~g} \mathrm{l}^{-1}$ humic acid as compared with control which needed to (81.33) days. Although the first and second concentrations of humic acid and first concentrations of benzyladenine was not effect significantly in the no. of days required to convert inflorescence bud to full inflorescence whilst the third concentration of humic acid $\left(0.15 \mathrm{~g} \mathrm{l}^{-1}\right)$ and (150 $\mathrm{mg} \mathrm{l}^{-1}$ ) of BA reduced significantly the no. of days required to convert inflorescence bud to full inflorescence as compared with control. At the same time spraying plants with humic acid at $\left(0.15 \mathrm{~g} \mathrm{l}^{-1}\right)$ caused significant increase in the no. of days remain inflorescence on the plant as compared with control which remained (5.50) days. Also humic acid at $\left(0.1 \mathrm{~g} \mathrm{l}^{-1}\right)$ caused significant increase in the no. of inflorescences/ plant and length of inflorescence stalk compared with untreated plants which recorded least value.

Table (3): Effect of humic acid and benzyladenine on days required to inflorescence bud initiation, no. of days required converting inflorescence bud to full inflorescence, no. of days remain inflorescence on the plant, no. of inflorescences/ plant and length of inflorescence stalk of pot marigold.

\begin{tabular}{|c|c|c|c|c|c|}
\hline conc. & $\begin{array}{l}\text { Days required to } \\
\text { inflorescence } \\
\text { bud initiation }\end{array}$ & $\begin{array}{l}\text { No. of days } \\
\text { required to } \\
\text { convert } \\
\text { inflorescence } \\
\text { bud to full } \\
\text { inflorescence }\end{array}$ & $\begin{array}{l}\text { No. of days } \\
\text { remain } \\
\text { inflorescence on } \\
\text { the plant }\end{array}$ & $\begin{array}{c}\text { No. of } \\
\text { inflorescences / } \\
\text { plant }\end{array}$ & $\begin{array}{c}\text { Length of } \\
\text { inflorescence } \\
\text { stalk (cm) }\end{array}$ \\
\hline Control & $81.33 \mathrm{a}$ & $7.89 a$ & $5.50 \mathrm{c}$ & $18.55 d$ & $17.19 \mathrm{~b}$ \\
\hline HA $0.05 \mathrm{~g} \mathrm{l}^{-1}$ & $64.28 \mathrm{~b}$ & $7.00 \mathrm{ab}$ & $7.50 \mathrm{bc}$ & $25.67 \mathrm{a}-\mathrm{c}$ & $20.36 a b$ \\
\hline HA $0.1 \mathrm{~g} \mathrm{I}^{-1}$ & $71.23 \mathrm{~b}$ & $7.83 \mathrm{a}$ & $7.33 \mathrm{bc}$ & $29.33 \mathrm{a}$ & $23.60 \mathrm{a}$ \\
\hline HA $0.15 \mathrm{~g} \mathrm{l}^{-1}$ & $55.88 \mathrm{c}$ & $5.50 \mathrm{c}$ & $10.33 \mathrm{a}$ & $26.17 \mathrm{ab}$ & $21.34 \mathrm{a}$ \\
\hline BA $50 \mathrm{mg} \mathrm{l}^{-1}$ & $64.50 \mathrm{~b}$ & $7.33 \mathrm{ab}$ & $7.00 \mathrm{bc}$ & $20.28 d$ & $19.82 \mathrm{ab}$ \\
\hline BA $100 \mathrm{mg} \mathrm{l}^{-1}$ & $65.78 \mathrm{~b}$ & $6.33 \mathrm{bc}$ & $7.50 \mathrm{bc}$ & $22.00 \mathrm{~cd}$ & $21.27 \mathrm{a}$ \\
\hline BA $150 \mathrm{mg} \mathrm{l}^{-1}$ & $69.83 \mathrm{~b}$ & $5.33 \mathrm{c}$ & $8.00 \mathrm{~b}$ & $24.83 b c$ & $21.45 \mathrm{a}$ \\
\hline
\end{tabular}

* Mean with the same letter and each parameter are not significantly different at 0.05 level according to Duncan multiple range test.

Spraying pot marigold plants with different concentrations of of humic acid and benzyladenine shows there are no significant increases in the inflorescence diameter between them, but there were significantly increased as compared to the control as displayed in Table (4). The highest no. of ray flowers/ inflorescence (56.22 flowers) was observed as a result of spraying plant with $0.15 \mathrm{~g} \mathrm{l}^{-1}$ humic acid as compared to the control which produce (32.67) flowers, while, the first concentration of humic acid $\left(0.05 \mathrm{~g} \mathrm{l}^{-1}\right)$ was significantly increased in the fresh weight of inflorescence $(1.69 \mathrm{~g})$ as compared to untreated plants (1.04) g. Data also showed that the dry weight of inflorescence and vas life was significantly affected by the concentrations of humic acid, the highest concentration of it gave maximum values of dry weight of inflorescence and vas life $(0.42 \mathrm{~g})$ and (7.17 days) respectively, compared to the control treatment that gave lower rates. 
Table (4): Effect of humic acid and benzyladenine on inflorescence diameter, no. of ray flowers/ inflorescence, fresh weight of inflorescence, dry weight of inflorescence and vas life of pot marigold.

\begin{tabular}{|c|c|c|c|c|c|}
\hline conc. & $\begin{array}{l}\text { Inflorescence } \\
\text { diameter }(\mathrm{cm})\end{array}$ & $\begin{array}{c}\text { No. of ray } \\
\text { flowers/ } \\
\text { inflorescence }\end{array}$ & $\begin{array}{c}\text { Fresh weight of } \\
\text { inflorescence } \\
\text { (g) }\end{array}$ & $\begin{array}{c}\text { Dry weight of } \\
\text { inflorescence } \\
(\mathrm{g})\end{array}$ & Vas life (days) \\
\hline Control & $4.37 \mathrm{~b}$ & $32.67 \mathrm{~d}$ & $1.04 b$ & $0.21 b$ & $4.33 \mathrm{c}$ \\
\hline HA $0.05 \mathrm{~g} \mathrm{l}^{-1}$ & $5.20 \mathrm{a}$ & $39.17 \mathrm{~cd}$ & $1.69 \mathrm{a}$ & $0.38 \mathrm{a}$ & $5.17 \mathrm{bc}$ \\
\hline HA $0.1 \mathrm{~g} \mathrm{l}^{-1}$ & $5.03 \mathrm{a}$ & $42.55 \mathrm{bc}$ & $1.63 \mathrm{a}$ & $0.36 \mathrm{a}$ & $6.00 \mathrm{a}-\mathrm{c}$ \\
\hline HA $0.15 \mathrm{~g} \mathrm{l}^{-1}$ & $5.07 \mathrm{a}$ & $56.22 \mathrm{a}$ & $1.31 \mathrm{ab}$ & $0.42 \mathrm{a}$ & $7.17 \mathrm{a}$ \\
\hline BA $50 \mathrm{mg} \mathrm{l}^{-1}$ & $5.47 \mathrm{a}$ & $48.50 \mathrm{ab}$ & $1.47 \mathrm{ab}$ & $0.30 a b$ & $5.50 \mathrm{a}-\mathrm{c}$ \\
\hline BA $100 \mathrm{mg} \mathrm{l}^{-1}$ & $5.20 \mathrm{a}$ & $46.00 \mathrm{bc}$ & $1.47 \mathrm{ab}$ & $0.38 \mathrm{a}$ & $6.67 \mathrm{ab}$ \\
\hline BA150 $\mathrm{mg} \mathrm{l}^{-1}$ & $5.57 \mathrm{a}$ & $50.50 a b$ & $1.62 \mathrm{a}$ & $0.38 \mathrm{a}$ & $6.17 \mathrm{a}-\mathrm{c}$ \\
\hline
\end{tabular}

* Mean with the same letter and each parameter are not significantly different at 0.05 level according to Duncan multiple range test.

\section{DISCUSSION}

Foliar application of humic acid had a promoting influence on the vegetative and flowering growth characters of pot marigold, since spraying plants with humic acid led to increase in number of leaves/ plant, no. of main branches, total chlorophyll in leaves, fresh weight of roots/ plant, dry weight of roots/ plant and roots length as compared to untreated plants, this effect may be due to the effects of humic substances on the growth of plants are recognized by morphological, physiological and biochemical effects (Nardi et al., 2002). AbdelMawgoud et al. (2007) have mentioned that the positive effect of humic acid's ability to nutrients uptake may be because of it's effect on plant dry biomass, also (Zhang and Ervin 2004) mentioned that the presence of iron in the humic acids or their colloidal nature have a real influence on the growth of different microorganisms which may excrete a range of vitamins, growth matters and antibiotics and these may active plant growth. Application Potassium-humate to the plants caused to increasing and improving growth traits of plants (Zaky et al., 2006) and (Karakurt and Padem, 2009). Abolina and Tashkhadzhaev (1968) indicated that the coal-Humic fertilizers promoted the biochemical processes in plants (respiration, photosynthesis and chlorophyll content). Similar result had been observed the influences of humic substances on plant growth, showed improved effects on growth independent of nutrition (Dursun et al., 2002).
In addition to the effect of humic acid on plant growth characters also it affected on flowering growth which caused increases in the no. of days remain inflorescence on the plant, no. of inflorescences/ plant, length of inflorescence stalk, no. of ray flowers/ inflorescence, fresh weight of inflorescence, dry weight of inflorescence, vas life and reduce days required to inflorescence bud initiation as compared to control treatment, this effect may be attributed as mentioned by (Azooz, 2009) and (Abd EL-Aal et al., 2005) that humic acid increase photosynthesis, chlorophyll density and plant root respiration which resulted in major plant growth also the beneficial effect of humic acid on plant growth may be because to its playing as source of plant growth hormones yield. This agreed with the results found by (Ahmad, 2013) who observed that the humic acid enhance vegetative and flowering growth. Humic acid substance has auxin-like activity, improved nutrient uptake which may be responsible for the longer vase life of cut stems (Baldotto and Baldotto, 2013). This effect is agreement with Ricardo et al. (1993), in his studies who stated that the application of humic acid produced earlier flowering and higher yield in marigold. Application of humic at $500 \mathrm{mg} \mathrm{l}^{-1}$ acid produced higher and healthier plant growth and enhanced flower yield and quality of gerbera (Nikbakht et al., 2015).

On the other hand, The reason of improving the growth and flowering of pot marigold, in no. of lateral branches, (N-S) plant spread, (E-W) 
plant spread, fresh weight of vegetative growth/ plant, dry weight of vegetative growth/ plant, no. of days required to convert inflorescence bud to full inflorescence and inflorescence diameter when plants treated with of benzyladenine as compared to control treatment, may be due to the important role of cytokinin in the regulation of the plant cell cycle and many developmental processes, also it promote growth and development of plant organs, detention of chlorophyll, translocation of nutrient (Pandey and Sinha, 1984). Al-hasnawi (2011) was observed that the cytokinins improve the nitrogen content on leaves which is essential in the formation of protein, nucleic acid, chlorophyll, enzyme, vitamins and plant hormones. cytokinin which has been found essential for gene expression at transportation level, cellular division and growth, produce naturally within plants which led to increase in flower size, plant height, breaking of dormancy, resistance to biotic and abiotic stress and branch strength (Hossein et al., 2007). These results were in accordance with many reports which have shown that the cytokinins are actively stimulated earliness and delaying senescence (Mok, 1994). BA increase dry mass production by stimulates cell division and chlorophyll accumulation that help to activate photosynthesis and accumulation of dry matter (Abou Aziz, 2011). Eraki (1994a) in his study on Hibiscus sabdarijfa L. plants stated that use of BA significantly increased plant height, number of branches in additional of fresh and dry weights of leaves. Application of BA on Zantedeschia aethiopiea caused to increase number of leaves (Majidian, 2012). Delay senescing effect of BA help to increase postharvest life of ornamentals as mentioned by (Subhashini et al., 2011) on Dracaena.

\section{CONCLUSION]}

According to the results obtained in this study that the humic acid and benzyladenine had promoting effect on the growth of pot marigold which produced highest vegetative growth also it had active role in the pot marigold flowers characters as compared with control.

\section{REFERENCES}

-Abd EL-Aal, F., M. R. Shafeek, A. A. Ahmed and A. M. Shaheen. (2005). Response of growth and yield of onion plants to potassium fertilizer and humic acid. Journal of Agricultural Sciences Mansoura University, 30(1):441-452.

-Abdel-Mawgoud, A. M. R., N. H. M. ElGreadly, Y. I. Helmy and S. M. Singer. (2007). Responses of Tomato Plants to Different Rates of Humic-based Fertilizerand NPK Fertilization. Journal of Applied Sciences Research, 3. 169-174.

-Abolina, B. I. and A. T. Tashkhadzhaev. (1968). Effects of Coal-Humic Fertilizers on the Activity of Physiological Processes in Plants and in the Yield of Potatoes in Uzbekistan. Guminovye Udabr. Guminovye Udabr, 1: 118-126.

-Abou Aziz, A. B., E.S. Hegazi, T.A., Yehia, N. E. Kassim and T. S. M. Mahmoud. (2011). Growth, flowering and fruiting of manzanillo olive trees as affected by benzyladenine. Journal of Horticultural Science and Ornamental Plants, 3 (3), pp: 244-251.

-Ahmad, I., R.U. Saquib, M., M. Qasim, Saleem , A.S. Khan and M. Yaseen. (2013): Humic acid and cultivar effects on growth, yield, vase life, and corm characteristics of gladiolus. Chilean Journal of Agricultural Research, 73(4): 339-344.

-Al-hasnawi A. N. H. (2011). Effect of benzyladenine and chelated magnesium spraying on growth and flowering of Chrysanthemum hortorum Hort. M.Sc. Thesis. Department of Horticulture and Landscape, College of Agriculture, University of Kufa, Iraq.

-Arancon, N.Q., S. Lee, C. A. Edwards and R. Atiyeh. (2003). Effect of humic acids derived from cattle, food and paperwaste vermicompost on growth of green house plants. Pedobiologia, 47:741-744.

-Atafar, Z., A. Mesdaghinia, J. Nouri, M. Homaee, M. Yunesian, M. Ahmadimoghaddam and A.H. Mahvi. (2010). Effect of fertilizer application on soil heavy metal concentration. Environment Monit Assess, 160(1-4): 8389.

-Azooz, M. M. (2009). Foliar application with riboflavin (vitamin B2) enhancing the resistance of Hibiscus sabdarffa, L. (Deep 
Red Variety) to salinity stress. Journal of Biology science, 9(2):109-118.

-Baldotto, M. A. and L. E. B. Baldotto. (2013). Gladiolus development in response to bulb treatment with different concentrations of humic acids. Revista Ceres 60:138-142.

-Dursun, A. I. Güvenç and M. Turan. (2002). Effects of different levels of humic acid on seedling growth and macro and micronutrient contents of tomato and eggplant. Acta Agrobotanica 56: 81-88.

_Eraki, M. A. (1994a). The effect of gibberellic application and chelated iron nutrition on the growth and flowering of Queen Elizabeth rose plants. The First Conference of Ornamental Horticulture, 2, 436-444.

-Fan, H.M., X.W. Wang and X. Sun. (2014). Effects of humic acid derived from sediments on growth, photosynthesis and chloroplast ultrastructure in chrysanthemum. Scientia Horticulturae 177: 118-123.

-Gadimov, A., N. Ahmaedova and R. C. Alieva. (2007). Symbiosis nodules bacteria Rhizobium leguminosarum with Peas (Pisum Sativum) nitrate reductase, salinification and potassium humus. Azarbayjan National Academy of Sciences. International Humic Substances Society. What are humic substances? Focus on form: Retrieved May 27, 2009, from

http://ihss.gatech.edu/ihss2/whatarehs.htm 1.

-Golestani, M., A. Dolatkhahi and F. Kazemi. (2013) Effect of Planting Dates on Flowering Period of Calendula officinalis, Bellis perennis and Viola sp. Advanced Crop Science, 3(8): 563-567.

-Han, S.S. (2001). Benzyladenine and gibberellines improve post - harvest quality os cut Asiatic and Orintallilies. Horticulture Science, 36, 741-745.

-Hossein, A., Saeidnejad and P. Rajaei. (2007). Ant oxidative Responses to Drought and Salinity Stress in marigold Plants. International Journal of Life Sciences 9 (2): 1-8.

-Karakurt, Y., H. Unlu and H. Padem. (2009).The influence of foliar and soil fertilization of humic acid on yield and quality of pepper. Acta Agriculture. Scandinavica. 59(3): 233-237.

-MacCarthy, P., C. E. Clapp, R. L. Malcolm and P. R. Bloom. (1990). An introduction to soil humic substances" In: P. MacCarthy et al. (eds.). Humic substances in soil and crop sciences: selected readings. American Society of Agronomy, Madison, WI. pp. 1-12.

-Majidian, N., A. Nadari and M. Majidian. (2012). The Effect of Four Levels of GA3 and BA on The Quantitative and Qualitative Characteristics of Zantedeschia aethiopica cv. Childsiana Pot PlantJournal Horticulture Plant, 25(4): 361-368.

-Menesi, F.A., E. M. S. Nofal and E. M. ElMahrouk. (1991). Effect of some growth regulators on Calendula officinalis $\mathrm{L}$. Egypt. J. Appl. Sci., 6:1-15.

-Mohammad, S. M. and H. H. Kashani. (2012). Pot marigold (Calendula officinalis) medicinal usage and cultivation. Scientific Research and Essays, 7(14): 1468-1472.

-Mohammadipour, E., A. Golchin, J. Mohammadi, N. Negahdar and M. Zarchini. (2012). Improvement Fresh Weight and Aerial Part Yield of Marigold (Calendula officinalis L.) by Humic Acid. Annals of Biological Research. 3(11): 5178-5180.

-Mok, M. C. (1994). In Cytokinins: Chemistry, Activity, and Function pp. 155-166, CRC Press, Inc., Boca Raton, FL.

-Mooney, P.A. and J. Van Staden. (1986). Algae and Cytokinins. Journal Plant physiology. 123, 1-21.

-Mutui, T.M., V.N. Emongor and M.J. Hutchinson. (2004). Effect of benzyladenine on the vase life and keeping quality of Alstoemeria cut flowers. Food and Agriculture Organization of the United Nations, 5(1): 91-105.

— Nardi S., D. Pizzeghello, A. Muscolo and A. Vianello. (2002). Physiological effects of humic substances on higher plants. Soil Biology and Biochemistry, 34, 15271536.

-Nikbakht, A., Kafi, M. Babalar, M., P.Y. Xia, A. Luo and N. Etemadi. (2015). Effect of humic acid on plant growth, nutrient 
uptake, and postharvest life of gerbera. Journal of Plant Nutrition, 31: 2155-2167.

-Nuvale, M. U., S. A. Aklade, J. R. Desai and P. V. Nannavare. (2010). Influence of PGR's on growth, flowering and yield of chrysanthemum (Dendranthem grandiflora Tzvelev) cv. 'IIHR-6'. International Journal Pharmancy and Bioscience, 1 (2): 1-4.

-Pandey, S. N. and B. K. Sinha. (1984). Role of Auxin. Plant Physiol., Vikash Publishing House, New Delhi. pp. 432-436.

-Rawia, A. and H. Bedour Abou-Leila. (2006). Response of croton plants to gibberellic acid, benzyladenine and ascorbic acid application. World J. Agr. Sci., 2, 174179.

-Ricardo, R., P. Raymond, Poincelot and P. B. Graeme. (1993).The use of a commercial organic bio-stimulant for improved production of marigold cultivars. Journal of Home and Consumer Horticulture 1:83-93.

-Rigane, G., S. Ben Younes, H. Ghazghazi and R. Ben Salem. (2013). Investigation into the biological activities and chemical composition of Calendula officinalis L. growing in Tunisia. International Food Research Journal, 20(6): 3001-3007.

-SAS, (2007).Institute, Inc "Statistical Analysis System. SAS institute Inc." Cary, NC. USA.

-Subhashin, R. M. B, N .L. K. Amarathunga, S. A. Krishnarajah and J. P. Eeswaral. (2011). Benzyle adenine effect for growth in petunia plants. Ceylon Journal of Science (Bio-Science.) 40 (2): 157-162.

-Tan, K. H. (1998). Principles of Soil Chemistry. (3rd edition), p: 267. Marcel Dekker, Inc. New York, USA.

-Zaky, M. H., O. R. El-Zeiny and M. E. Ahmed. (2006). Effects of humic acid on growth and productivity of bean plants grown under plastic low tunnels and open field. Egypt. Journal Applied Science, 21(4):582-596.

-Zhang, X. and E. H. Ervin. (2004). Cytokinincontaining seaweed and humic acid extracts associated with creeping bent grass leaf cytokinins and drought resistance. Crop Science, 44: 1737-1745. 


\section{كارتيّكرنا رهشاندنا بهلكى يا ترشى هيوميّك و بهنزل ئهدينين لسهر شينبوون}

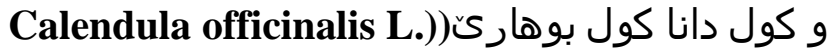

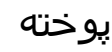

ئه ثهكولينه هاته كرن زهويثا جريائكن

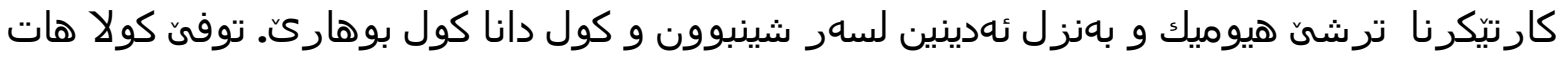

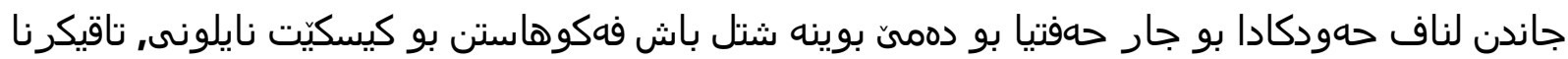

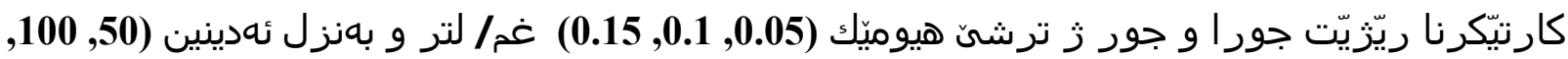

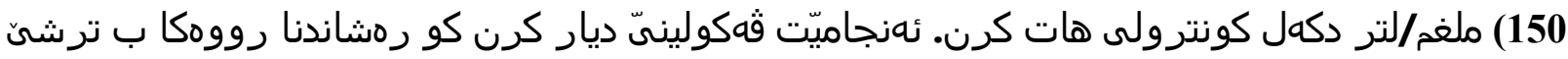

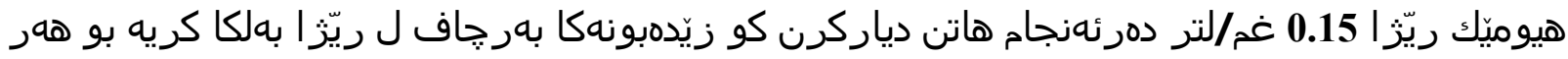

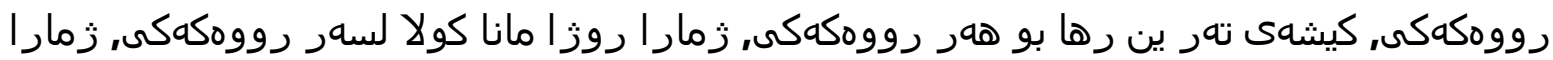

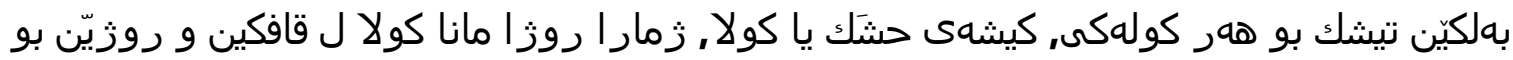

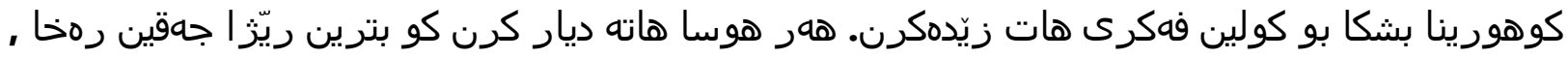

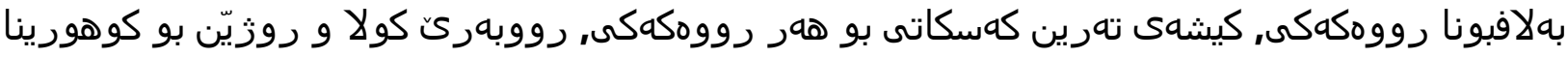

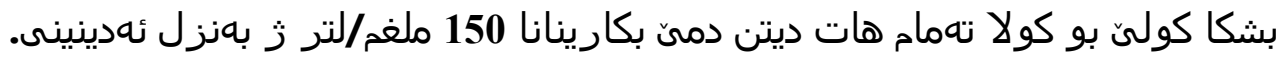

تalendula تأثير الرش الورقي لحامض الهيوميك و البنزل أدينين على النمو و التزهير نبات لأقحوان (officinalis L.)

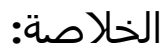

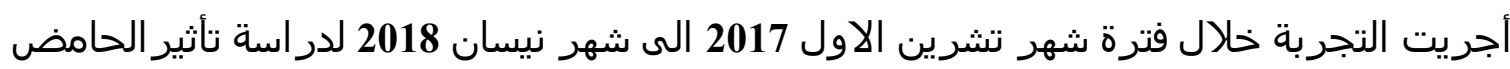

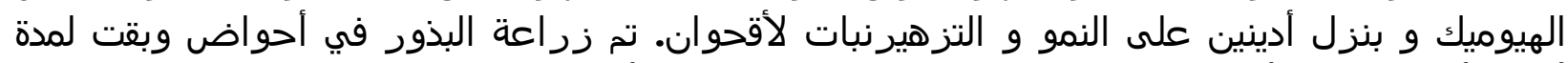

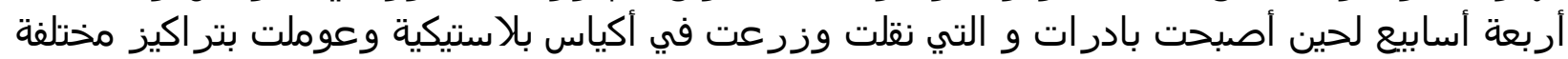

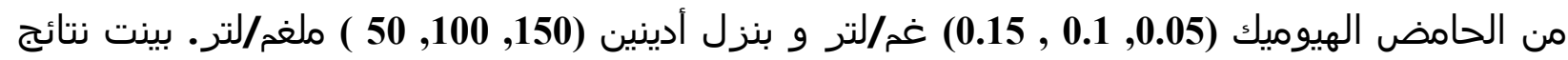

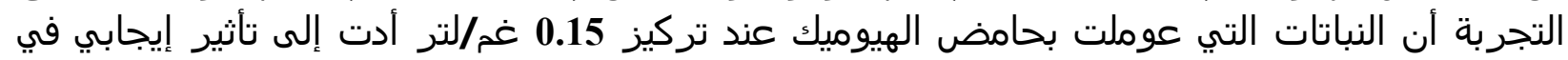

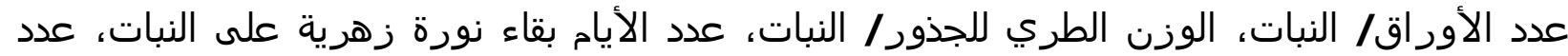

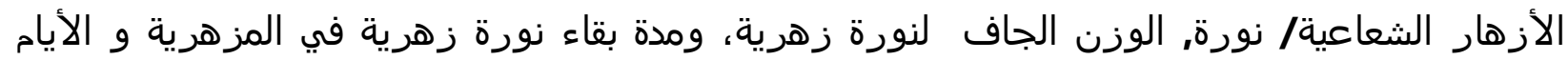

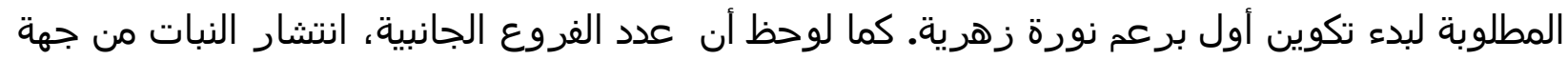

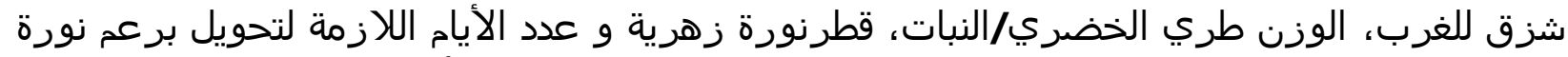

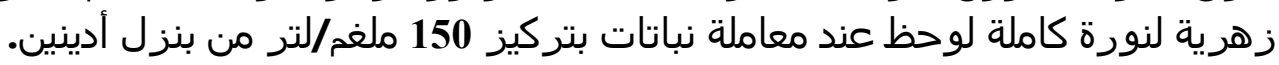

